\title{
Editorial
}

\section{Quality Management Systems: Subject to Continuous Improvement?}

Whatever is the way we do things today, it is already bad and old-fashioned. Every day we have to search for new, different and better ways of producing.

F. Cuba

Ever since John F. Magee, President of Arthur D. Little, Inc., identified management as an evolving technology [1], and proposed that it is and should be subject to continuous change, we are expected to bring forth the notion of technology improvement: the quality of management technology or more precisely, the quality of a management system.

Mr. Magee went even further and identified that the new management systems will (minimally) include (1) introducing market concepts into administered systems, and (2) the decline of 'hierarchical principles' of management. On both of these points he is now being proven correct.

Many of the alternative management systems (Japanese-style, Bat'a-system, Deming/Juran, IPM, etc.) emphasize that quality is not a matter of maintaining several quality attributes within prespecified limits, but a matter of continuous improvement, constant striving for the ideal.

Are then management systems themselves subject to this need for continuous improvement and constant striving, or are they to be narrowly fixated and precisely defined, jealously warding off any 'deviations' from prespecified 'norm' or 'pure form'? Are the proponents of quality management systems striving for their improvement through continuous rethinking, adaptation and redefinition, or is there a danger of 'self-satisfaction' with what such man-

IOS

Human Systems Management 8 (1989) 1-3 agement systems have been and are today?

There are no clear answers to this, arguments pro and con can be made on both sides. If, however, such danger exists or is about to emerge, then its potential implications could be 'deadly'. There are some obvious issues, mostly related to system incompleteness, that are not fully addressed and thus could turn into serious omissions and shortcomings. For example,

1) Neglecting the crucial role of technology. About $40 \%$ of all new investment in plant and equipment in the U.S. now goes to purchase information technology [2]. These high technologies are increasingly informating [3] and even self-informating, capable of collecting, analyzing and acting upon information about themselves. Such technologies are significantly autonomous and self-controlling; The Japanese are speaking of autonomation (not automation) in this context. In practice, such machines are capable of monitoring, measuring and assessing the attributes of each of their own individual products. This puts our pretechnological emphasis on statistical sampling into a proper perspective.

2) Preoccupation with quality at the expense of creativity. Quality is necessary but not a sufficient dimension of the globally competitive business. Because both product and process quality can be measured and monitored through the use of statistical charts and analyses, there is a human tendency to emphasize the statistically measurable quality and thus abdicate relevant management/organizational issues to statisticians. Yet, the name of the global game is increasingly creativity, more in the domain of 'creating appropriate conditions' (i.e., management) rather than in statistics.

3. Recognizing knowledge as capital is rarely 
explicit. Although productivity growth is affected by capital formation, fixed capital - plant and equipment - is only part of the total capital employed in business. So-called 'invisible' or 'intangible' capital, often treated as expense rather than investment (or as residual rather than major strategic asset), is now becoming the more important part [4]. Firms' 'invisible' (to accountants) assets, although varied and intricate, are all interwoven into the infrastructure of knowledge.

4) The need for employee co-ownership is not fully recognized. In a knowledge-oriented enterprise the employee not only participates in decisions and shares in profits, but must be an autonomous knowledge agent: a capitalist, co-owner of the enterprise. Successful forms of macro and micro employee-ownership (including full responsibility and full managerial rights) of the processes, workplaces, equipment or 'entrepreneurial microspaces' are not sufficiently studied and mastered.

5) Integrative aspects of quality management are not emphasized. The need for reintegration (rather than further division and specialization) is manifested in powerful trends towards reintegration of task (smaller number of parts, smaller number of process steps, parallel and overlapping processing), reintegration of labor (one worker-multiple tasks, one operator-multiple machines, self-service and do-it-yourself) and reintegration of knowledge (multifunctionality, cross- and transdisciplinarity, 'intelligent' end-user technologies).

These are typical examples of quality management areas that are in need of continuous development and improvement. Alternative management systems must be primarily systems, not collections or aggregates of methods, techniques or slogans.

Quality management systems are subject to continuous improvement and modernization: there should be nothing given, fixed, eternal or 'pure' about them. Only the most flexible, most adaptable and most human-nature matching management systems shall prevail and remain viable in newly emerging business ecologies.

The presidents of fourteen top European multinationals launched a joint foundation (European Foundation for Quality Management) aimed at boosting the role of managers in improving quality [5]. This broad cross-national campaign is based at the Dutch headquarters of Philips, which is spearheading the effort.

This European initiative is fundamentally different from similar 'quality movements' in the U.S.: its emphasis is not on the short-term training and retraining of practitioners, but on requesting educational institutions to provide more quality management courses. While Europeans do recognize the crucial and long-term role of knowledge, academic research and basic education, U.S. quality movements have not significantly influenced academic degree-granting university programs and thus encouraged short-term, profit-oriented, low-quality training and seminars providers to fill the void.

One of the European foundation's first tasks is to convince its potential audience that 'total quality management' is more than just an alternative formulation of the vague and mostly empty concepts of 'excellence' or 'world-classism' and that its members really do have something concrete to teach their peers. Both the journal of Human Systems Management and its focus on IPM (Integrated Process Management) [6] are therefore entrenching themselves fully and firmly where it counts - at the source.

The corresponding U.S.-initiated effort could be the CIOS (Conseil International pour Organisation Scientifique) XXI World Management Congress, scheduled for New York City on September 20-23, 1989. Its overall theme is 'Management Challenges for the 1990's' and among the key discussion issues are: Managing Innovation; Integration of New Technologies; Creative Talent as Capital; Alternative Management Systems; Managers-Owners; Competitiveness; Newly Industrializing Societies; Post-Multinational Corporation; Managing Systems vs. Functional Specialization and others. Needless to say, Human Systems Management is also going to be right there - at the source.

CIOS's innovative and challenging program should provide the necessary impetus and trigger for establishing similar Quality Management Business Consortia also in the U.S.A.

Below we summarize one version of the 'ten commandments' forming the system of Integrated Process Management (IPM):

1. Human knowledge is the most productive form of capital. Labor is changing to work and work 
is best performed by autonomous, multi-functional, responsible and team-rewarded 'knowledge agents'.

2. To be effective, knowledge should be integrated and enhanced by humans themselves. Employees must be empowered and responsible for coordinating their own actions and managing their own 'entrepreneurial microspaces'.

3. The necessary reintegration of task, labor and knowledge can be accomplished only in a democratic, integrative and non-hierarchical organization, via custom-made reward packages, integrative technologies and continuous education of individuals in teams.

4. Customers are the primary investors and stakeholders of the enterprise, its purpose and its driving force. They finance all current and future costs, taxes and profits. Their satisfaction comes first: through continually improved product and better prices. It is what the customers do (not what they say they do) that matters in business.

5. All employees are autonomous agents and serve as customers of each other. They enter contractual agreements and reciprocal arrangements to buy and sell their products and services reliably, on time, at the best quality, at the lowest price through intracompany market systems.

6. The gap between owners (external stockholders) and employees (managers and workers) must be reduced as well as the gap between coordinators (managers) and operators (workers). Hierarchical coordination by command is replaced by selfmanagement based on reciprocity and mutual adaptation.

7. Continuous maintenance and improvement of employees' total quality of life (not just the quality of 'work life') is the responsibility of the whole enterprise, that is, of its own equal coowners: employees.
8. Purposeful broadening and enhancement of flexibility, adaptability and responsiveness is the major task of strategic planning (not long-term forecasting). Optimal design and continuous improvement of systems takes precedence before running given systems efficiently.

9. Continued knowledge expansion is achieved through education, training, job rotation and creative enhancement of skills and talents of all employees. Employee education is one of the major responsibilities of knowledge enterprise.

10. All optimal management system principles should be derivable from or in harmony with the simple wisdom of treating the others as we ourselves would wish to be treated.

\section{References}

[1] John F. Magee, 'Management: an evolving technology', Human Systems Management, 1(1980)1, pp. 47-52.

[2] U.S. Congress Office, Office of Technology Assessment, Technology and the American Economic Transition: Choices for the Future, OTA-TET-283, Washington DC, May 1988.

[3] Shoshana Zuboff, In The Age of the Smart Machine, Basic Books, New York, 1988.

[4] George N. Hatsapoulos, Paul R. Krugman, Lawrence H. Summers, 'U.S. Competitiveness: Beyond the Trade Deficit', Science, 15 July 1988, pp. 299-307.

[5] 'European multinationals aim to lift managers' role', by W. Dawkins, Financial Times, September 16, 1988.

[6] Milan Zeleny, 'What is Integrated Process Management?' Human Systems Management, 7(1988)3, pp. 265-267.

Milan ZELENY

Graduate School of Business

Fordham University at Lincoln Center

New York, NY 10023

U.S.A. 